\title{
Some factors influencing the chemical composition of mixed rumen bacteria
}

\author{
By R. H. SMITH AND A. B. MCALLAN \\ National Institute for Research in Dairying, Shinfleld, Reading RG2 $9 A T$ \\ (Received 27 November $1972-$ Accepted I 8 7une 1973)
}

\begin{abstract}
x. Sheep, cows and calves fitted with rumen cannulas were given diets mostly containing Io-16 $\mathrm{g}$ nitrogen $/ \mathrm{kg}$ dry matter and consisting of roughage and cereals. Mixed bacteria were separated from samples of their rumen contents.

2. Bacteria taken $4-6 \mathrm{~h}$ after a feed from calves which were kept in an experimental calfhouse with no contact with adult animals (environment $A$ ) contained more $\alpha$-dextran, less total $\mathrm{N}$ and higher nucleic acid:total $\mathrm{N}$ ratios than similar bacteria from calves reared in contact with adult sheep (environment $\mathrm{C}$ ) but otherwise treated in an identical way.

3. Mixed bacteria taken $4-6 \mathrm{~h}$ after a feed from sheep and cows were similar in composition, with respect to nitrogenous components, to those from the 'environment $C$ ' calves. This composition did not vary significantly when diets containing differing proportions of roughage were given.

4. The 'environment A' calves were free of ciliate protozoa. When they were placed in contact with, and were inoculated with rumen contents from, adult cattle (environment B), they rapidly developed a normal protozoal population and the chemical composition of their rumen bacteria became like that of the bacteria from the 'environment C' calves.

5. Mixed bacteria taken just before a feed, from either cows or 'environment A' calves, showed significantly lower RNA-N: total N ratios and slightly (but not usually significantly) higher DNA-N : total $N$ ratios than bacteria taken $4-6$ h after feeding. Total $N$ contents of the bacteria did not change consistently with time after feeding.

6. The possible significance of these differences in relation to the nutrition of the host animal is discussed.
\end{abstract}

The bacterial population in the rumen generally contributes a considerable part of the nutrient material entering the small intestine of the ruminant. Knowledge of the chemical composition of this population and how it varies is necessary for a proper understanding of the nutrition of the host animal and to enable calculations to be made, for example, of the contribution of bacterial protcin and carbohydrate to the digesta. Results, generally for small numbers of samples, have been reported for total nitrogen, amino acids, nucleic acids, carbohydrates, lipids and ash as proportions of the dry matter in some samples of mixed rumen bacteria (Heald, 195I; Gibbons, Doetsch \& Shaw, 1955; Katz \& Keeney, I964; Bergen, Purser \& Cline, 1968; Milwid, Oliver \& Topps, I968; Hoogenraad \& Hird, I970; Mason \& Palmer, I97 I J Jouany \& Thivend, I972; Lindsay \& Hogan, I972; McAllan \& Smith, 1972; Smith \& McAllan, I972, I973).

It seems clear that at least some of these components must vary with factors such as diet and time after feeding, and this is supported in some instances by in vitro results (e.g. Heald, I95 I; Thompson \& Ilobson, 197I). There is, however, only a very limited amount of information on the extent of such variations under in vivo conditions (Walker \& Nader, 1970; Jouany \& Thivend, I972; McAllan \& Smith, 1972; Smith \& McAllan, 1972, 1973) and the factors responsible for them. The present 
work examines some of these factors, particularly the environment of the host animal and the time after feeding, in relation to possible effects on the nutrition of the host animal.

\section{EXPERIMENTAL AND RESULTS}

\section{Animals}

Calves (male animals castrated at about 6-I2 weeks of age), sheep and cows examined in these investigations were all equipped with rumen cannulas. The cannulas fitted in the cows were as described by Balch \& Cowie (1962) and those in the calves and sheep were similar to the cannulas described by Smith \& McAllan (1970). No collections of rumen digesta were made within 4 weeks of the operation to insert the cannulas which, for the calves, was carried out between 8 and i 5 weeks of age.

The cows were housed at Church Farm (National Institute for Research in Dairying) and were in close proximity to many other adult bovines. This will be referred to as environment B. The sheep were adult animals (more than I year old) and were kept either in environment B or in farm-type buildings close to other adult sheep at the Grassland Research Institute, Hurley, Berkshire. This will be referred to as environment C.

Some experimental calves were kept in environment $\mathrm{B}$ or $\mathrm{C}$ but most were kept in the experimental calf unit of the Nutrition Department, National Institute for Research in Dairying. This unit is housed in buildings equipped with concrete or metal pens with expanded-metal floors and will be referred to as environment A. It is separate from other buildings housing farm animals. No special precautions were adopted to ensure isolation from adult animals although staff handling the calves did not generally come into contact with other animals. After weaning over a period of about 2 weeks, at 4-7 weeks of age, the calves were first given a diet consisting of about equal weights of hay and a calf-rearing concentrate mixture. For this and other similar diets the concentrates were given twice a day (at 09.00 and 17.00 hours) and the roughage at 17.00 hours only. Experimental diets were introduced as required and were given for a period of at least $20 \mathrm{~d}$ before samples were taken. No collections of rumen contents were made within 9 weeks of weaning. Samples were sucked from the ventral sac of the rumen by means of a tube with an internal diameter of about $10 \mathrm{~mm}$. They were collected into a vessel surrounded by ice and strained through muslin or plastic mesh to remove coarse food particles. A sample of strained fluid was centrifuged at $200 \mathrm{~g}$ for $5 \mathrm{~min}$. The supernatant fraction was recentrifuged at $200 \mathrm{~g}$ for the same time and then, after again discarding the residue, at $30000 \mathrm{~g}$ for $15 \mathrm{~min}$. The sediment from this centrifugation was washed, first with $\mathrm{NaCl}$ solution $(9 \circ \mathrm{g} / \mathrm{l})$ and then with water, separation after each washing being effected by centrifuging at $30000 \mathrm{~g}$ for $\mathrm{I} 5 \mathrm{~min}$. The final sediment consisted of bacteria and was virtually free of protozoa or food debris. This was shown by microscopical examination and by the very small amounts of xylose and arabinose in acid hydrolysates of the samples (less than $2 \mathrm{~g} / \mathrm{kg}$ dry matter). 
Table 1 . Composition of samples of mixed bacteria separated from rumen digesta taken from sheep, cows and calves

(Samples were taken $4^{-6} \mathrm{~h}$ after a feed had been given. Calves aged $15-43$ weeks were kept in environment $A$ (see p. 28). Results are presented as mean values with their standard errors derived from observations on individual animals. These observations were themselves generally the means for at least two experiments)

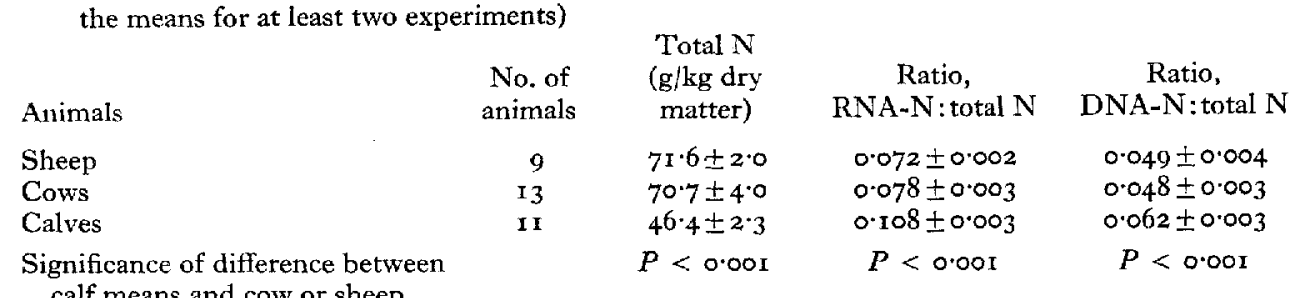
calf means and cow or sheep means

Table 2. Composition of samples of mixed bacteria separated from rumen digesta taken from sheep and cows given different diets

(Samples were taken $4^{-6} \mathrm{~h}$ after a feed had been given. Results are presented as mean values with their standard errors derived from observations on individual animals. These observations were themselves generally the means for at least two experiments)

\begin{tabular}{|c|c|c|c|c|c|}
\hline Animals & Diet & $\begin{array}{l}\text { No. of } \\
\text { animals }\end{array}$ & $\begin{array}{l}\text { Total N } \\
\text { (g/kg dry } \\
\text { matter) }\end{array}$ & $\begin{array}{c}\text { Ratio, } \\
\text { RNA-N: total N }\end{array}$ & $\begin{array}{c}\text { Ratio, } \\
\text { DNA-N: total N }\end{array}$ \\
\hline \multirow[t]{2}{*}{ Sheep } & All hay & 5 & $68 \cdot 1 \pm 3 \cdot 8$ & $0.074 \pm 0.001$ & $0.050 \pm 0.003$ \\
\hline & $\begin{array}{l}400-700 \mathrm{~g} \text { concentrates } / \mathrm{kg} \\
\text { remainder hay }\end{array}$ & 3 & $77 \cdot 4 \pm 7 \cdot 9$ & $0.076 \pm 0.004$ & $0.044 \pm 0.013$ \\
\hline \multirow[t]{2}{*}{ Cows } & All hay & 2 & $73 \cdot 7 \pm 0.5$ & $0.080 \pm 0.001$ & $0.046 \pm 0.012$ \\
\hline & $\begin{array}{l}700-800 \mathrm{~g} \text { concentrates } / \mathrm{kg} \\
\text { remainder hay }\end{array}$ & 4 & $72 \cdot 9 \pm 7 \cdot 6$ & $0.078 \pm 0.002$ & $0.034 \pm 0.004$ \\
\hline
\end{tabular}

There were no significant differences between the diets.

\section{Analytical methods}

Nucleic acids were determined according to McAllan \& Smith ( 1969 ), total $\mathrm{N}$ as described by Smith \& McAllan (1970) and $\alpha$-dextran as glucose liberated by refluxing for $4 \mathrm{~h}$ with $0.5 \mathrm{M}-\mathrm{H}_{2} \mathrm{SO}_{4}$ (previously referred to as 'starch'-glucose) as described by Smith \& McAllan (1972).

\section{Differences between calves, sheep and cows}

Calves, for which results are given in Table $\mathrm{I}$, were kept in environment $\mathrm{A}$ and received $50-90 \%$ of their intake as cereals (flaked maize, rolled barley or oats) with vitamin and mineral supplements. The rest of their intake consisted of hay or straw. Most of the sheep and cows, for which results are shown in Table I, were also given diets containing concentrates and roughage. The concentrates were commercial products prepared mainly from cereals (maize, wheat and barley) with various protein supplements and comprised 1o- $80 \%$ of the diet with the remainder consisting of hay, straw or dried grass. A few experiments were made with diets consisting only of hay or dried grass. Mean $\mathrm{N}$ contents of the diets received by the different animals were 


\section{Table 3. Composition of samples of mixed bacteria separated from rumen digesta taken from calves kept in different environments}

(Samples were taken $4 \mathrm{~h}$ after the calves received a flaked maize feed (for details, see p. 28). Each result is presented as a mean value with its standard error derived from observations on each of three animals. With one exception, these observations were themselves means for three experiments with each animal. The exception was an $\alpha$-dextran result for one 'environment $C$ ' calf, for which a single value only was obtained)

$\begin{array}{lcccc} & \begin{array}{c}\text { Total N } \\ \text { (g/kg dry } \\ \text { matter) }\end{array} & \begin{array}{c}\text { Ratio, } \\ \text { RNA-N:total N }\end{array} & \begin{array}{c}\text { Ratio, } \\ \text { DNA-N:total N }\end{array} & \begin{array}{c}x \text {-dextran } \\ \text { (g/kg dry } \\ \text { matter) }\end{array} \\ \text { Environment A } & 50.8 \pm \mathrm{I} \cdot 6 & 0.108 \pm 0.005 & 0.062 \pm 0.009 & \operatorname{lrg} \pm \mathrm{I} 8 \\ \text { Environment C } & 8 \mathrm{I} \cdot 9 \pm 8.7 & 0.077 \pm 0.002 & 0.056 \pm 0.005 & 54 \pm \mathrm{II} \\ \text { Significance of difference } & P<0.05 & P<0.01 & \mathrm{NS} & P<0.05\end{array}$

NS, not significant.

very similar $\left(\mathrm{I}_{4} \cdot 2, \mathrm{I}_{5} \cdot 5\right.$ and $14.6 \mathrm{~g} / \mathrm{kg}$ dry matter for the sheep, cows and calves respectively) and all the diets contained between $\mathrm{ro}$ and $\mathrm{I} 6 \mathrm{~g} \mathrm{~N} / \mathrm{kg}$ dry matter. Appreciable variations in bacterial composition due to differences in $N$ intake (Smith \& McAllan, r973) were therefore unlikely. Comparisons within the sheep and cows showed that the variations in relative proportions of concentrates to roughage also had little effect on the nitrogenous constituents of the rumen bacteria (Table 2). Thus, although the groups of different animals did not receive identical diets it seems improbable that the marked and consistent differences shown in Table $\mathrm{I}$ between total $\mathrm{N}$ contents and nucleic acid $\mathrm{N}$ : total $\mathrm{N}$ ratios for rumen bacteria from calves on the one hand and from sheep or cows on the other hand were due to dietary differences. No differences between sheep and cows were apparent.

\section{Differences between calves kept in different environments}

At about $4 \mathrm{~d}$ of age, three calves were placed into each of two groups. The calves in one group were raised in environment $\mathrm{A}$ according to our usual practice. The calves in the other group were transferred to environment $\mathrm{C}$ where they were housed in pens adjacent to, and allowing direct contact with, adult sheep. All the calves were weaned between 7 and 9 weeks onto a diet of approximately equal weights of flaked maize (given in the feeds at about 09.00 and 17.00 hours) and hay (given at 17.00 hours only). Sufficient amounts were provided for a growth rate of about $0.4 \mathrm{~kg} / \mathrm{d}$ and suitable mineral and vitamin supplements were also given. At 10-1 2 weeks the calves were provided with rumen cannulas and were castrated. Starting at 18 weeks of age and at subsequent intervals of about $\mathrm{I}$ week, three samples of rumen contents (about I 1) were taken from each of the calves $4 \mathrm{~h}$ after their morning feed. The amounts of total $N$, nucleic acid $N$ and $\alpha$-dextran in the bacteria contained in these samples are given in Table 3 .

There were very marked differences between the groups of calves. Those kept in environment A gave bacterial samples closely similar in composition to those obtained previously from similarly fed calves. The calves kept in environment $\mathrm{C}$, on the other hand, gave bacteria showing a composition like that found previously for bacteria 


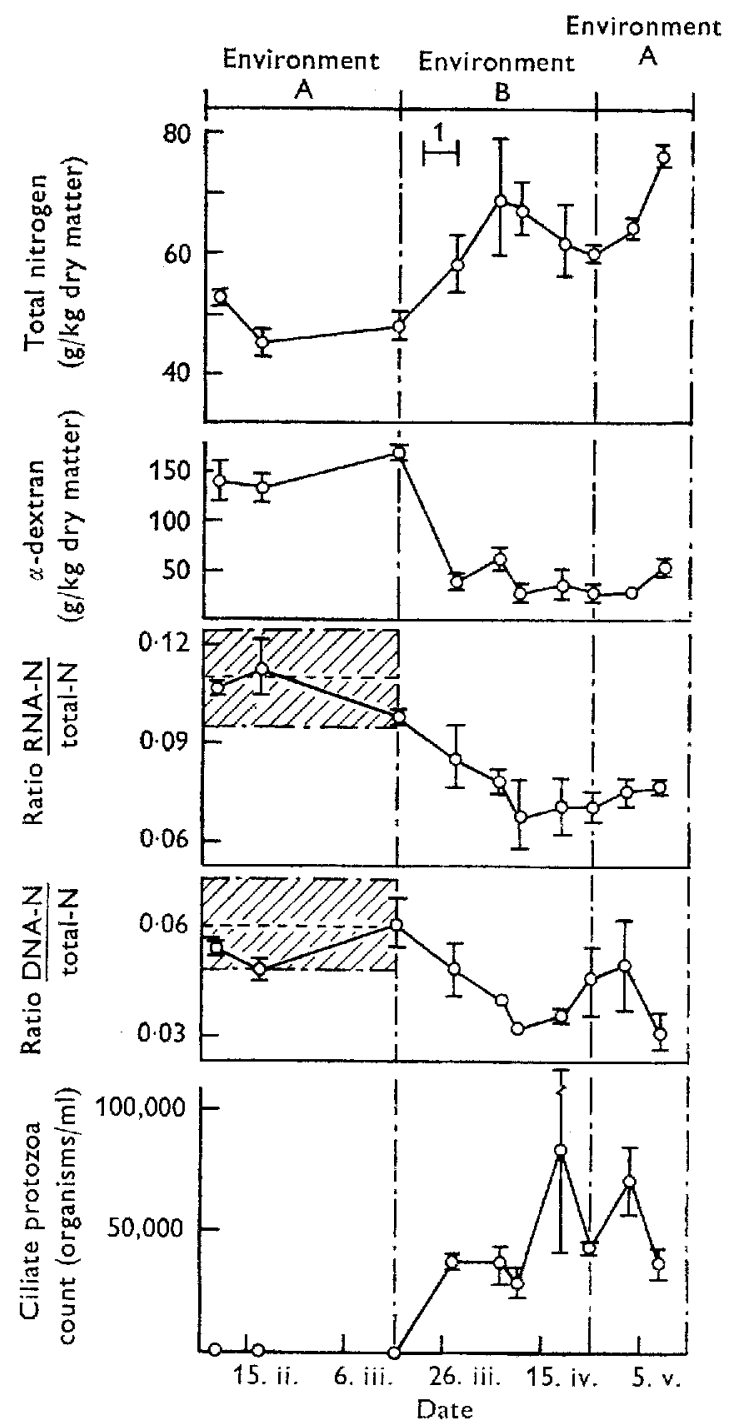

Fig. I. Changes in numbers of rumen ciliate protozoa and in the composition of samples of rumen bacteria from two calves transferred between two environments. Environments $A$ and $B$ are described on p. 28. Daily inoculations of $100 \mathrm{ml}$ rumen contents from a cow with an established protozoal population were given during the period marked $\mathbf{I}$. Results are given as means for the two animals with their standard errors shown as vertical bars. For the nucleic acid results, horizontal broken lines with surrounding shaded areas indicate mean values and standard deviations of individual values determined for sixty-two samples from calves kept in environment $A$.

from sheep and cows (Table I; and Smith \& McAllan, I973). It seemed most likely that these differences were brought about by the different opportunities which the environments gave for the invasion of the rumen by micro-organisms. This possibility was investigated by studying the direct effect of encouraging an invasion of the rumens of calves previously kept in environment $\mathrm{A}$ by micro-organisms from adult 
Table 4. Variations in the composition of mixed bacteria separated from rumen digesta taken from calves and cows at different times after feeding

(Calves aged 32-43 weeks were kept in environment A (see p. 28). All animals were given diets containing both hay and concentrates. Nitrogen contents of the diets were $16-24 \mathrm{~g} / \mathrm{kg}$ dry matter for the calves and ro- $16 \mathrm{~g} / \mathrm{kg}$ dry matter for the cows. Results in the first group are expressed as mean values with their standard errors for replicate experiments on one calf. The remaining results are expressed as mean values with their standard errors for single observations on each of several animals. Paired comparisons showed that the values marked * or ** were significantly different $(P<0.05$ or 0.01 respectively) from the corresponding before-feeding values)

\begin{tabular}{|c|c|c|c|c|c|c|}
\hline Animals & $\begin{array}{c}\text { No. of } \\
\text { animals }\end{array}$ & $\begin{array}{c}\text { No. of } \\
\text { observations }\end{array}$ & $\begin{array}{l}\text { Time after } \\
\text { feeding } \\
\text { (h) }\end{array}$ & $\begin{array}{l}\text { Total N } \\
\text { (g/kg dry } \\
\text { matter) }\end{array}$ & $\begin{array}{c}\text { Ratio, } \\
\text { RNA-N: total N }\end{array}$ & $\begin{array}{c}\text { Ratio, } \\
\text { DNA-N : total N }\end{array}$ \\
\hline \multirow[t]{2}{*}{ Calves } & I & 6 & $\begin{array}{c}\text { Before } \\
2 \\
4 \\
6\end{array}$ & $\begin{array}{l}57 \cdot 0 \pm 2 \cdot 6 \\
57 \cdot 5 \pm 4 \cdot 8 \\
55 \cdot 8 \pm 4 \cdot 3 \\
56 \cdot 8 \pm 3 \cdot 6\end{array}$ & $\begin{array}{r}0.081 \pm 0.004 \\
0.088 \pm 0.009 \\
0.108 \pm 0.009 \\
0.116^{* *} \pm 0.008\end{array}$ & $\begin{array}{l}0.058 \pm 0.001 \\
0.054 \pm 0.006 \\
0.053 \pm 0.005 \\
0.052 \pm 0.003\end{array}$ \\
\hline & 3 & 3 & $\begin{array}{c}\text { Before } \\
4\end{array}$ & $\begin{array}{l}64 \cdot 8 \pm \text { I I } 6 \\
59 \cdot 3 \pm 9 \cdot 4\end{array}$ & $\begin{array}{r}0.093 \pm 0.006 \\
0.119^{* *} \pm 0.006\end{array}$ & $\begin{array}{l}0.074 \pm 0.021 \\
0.066 \pm 0.007\end{array}$ \\
\hline Cows & 5 & 5 & $\begin{array}{c}\text { Before } \\
2 \\
4 \\
6\end{array}$ & $\begin{array}{r}74 \cdot 6 \pm 4 \cdot 5 \\
75 \cdot 3 \pm 6 \cdot 1 \\
85 \cdot 1 * \pm 3 \cdot 2 \\
8 I \cdot 9 \pm 7 \cdot 0\end{array}$ & $\begin{array}{r}0.070 \pm 0.009 \\
0.082 \pm 0.007 \\
0.084^{* *} \pm 0.007 \\
0.084^{*} \pm 0.009\end{array}$ & $\begin{array}{r}0.060 \pm 0.005 \\
0.051 \pm 0.004 \\
0.052 \pm 0.004 \\
0.042 * \pm 0.009\end{array}$ \\
\hline
\end{tabular}

animals. Two calves were transferred from this environment to environment $B$ and daily samples $(100 \mathrm{ml}$ ) of rumen contents from a cow added to their rumens for $7 \mathrm{~d}$. Samples of rumen bacteria, taken from these calves $4 \mathrm{~h}$ after the morning feed, were prepared before, during and after this treatment. Values for composition of the bacteria, which are shown in Fig. $I$, changed from being typical of comparable samples from previous experiments using 'environment $A$ ' calves to being very similar to samples previously obtained from calves in environment $C$ and from sheep and cows.

No observations were made of possible differences in types of bacteria present under the different conditions. It was, however, found that whereas samples of rumen contents from the 'environment $C$ ' calves contained ciliate protozoa in numbers $\left(3^{-6} \times 10^{4}\right.$ organisms $\left./ \mathrm{ml}\right)$ similar to those reported for cattle receiving similar diets (Hungate, r966) samples of rumen contents from calves reared in 'environment $A$ ' contained none. This complete lack of rumen ciliate protozoa was shown for the three 'environment A' calves for which results are given in Table 3 and for four other similar calves. The changes in chemical composition of the mixed rumen bacteria when 'environment A' calves were subjected to the different conditions described in Fig. I were accompanied by the establishment of ciliate protozoa in their rumens.

\section{Variations with time after feeding}

Values reported so far have been for samples of bacteria separated from rumen contents taken $4^{-6} \mathrm{~h}$ after feeding. Values given in Table 4 show that samples taken at other times sometimes differed from these in composition. Although variations in total $\mathrm{N}$ content were not consistent, the RNA-N: total $\mathrm{N}$ ratios were significantly 
lower for bacteria taken before feeding for both cows and 'environment A' calves. Conversely, there was a tendency for DNA-N:total $\mathrm{N}$ ratios to be higher in the samples taken before feeding, although the differences were significant in only one instance.

\section{DISCUSSION}

For calves receiving diets consisting of equal weights of hay and cereals it appears that more than half of the N compounds (Smith \& McAllan, I973) and of the $\alpha$-dextranlike compounds (Smith \& McAllan, I972) entering the duodenum are derived from the rumen microbes. The present work has shown that for calves receiving diets like these, the chemical composition of the rumen microbes, and therefore the nutrients entering the duodenum, may be markedly influenced by changing the environment in which the calves are reared (Table 3 ). Although no measurements of absolute amounts of nutrients entering the duodenum were made, it was demonstrated, for example, that for calves reared in a secluded environment (environment A) a given expenditure of bacterial synthetic effort in the rumen yielded a smaller total amount of $\mathrm{N}$ compounds, of which a greater proportion consisted of nucleic acids, than for calves kept in contact with adult animals. Nucleic acids are of relatively little nutritional value to the host animal (Condon \& Hatfield, I970), so that differences such as these and the differences in bacterial composition observed at different times after feeding (Table 4 ) would probably lead to varying degrees of wastage of $\mathrm{N}$ resources by the animal. It is important that these differences be taken into account when attempts to estimate bacterial protein synthesis in the rumen are made (e.g. Walker, 1965; Smith, 1969; Henderickx, Demeyer \& van Nevel, 1972).

The reasons for the surprisingly clear-cut differences observed between the "environment A' calves, on the one hand, and the other groups of animals examined, on the other, are not established, but it seems most probable that they were related to a lack of opportunity for the 'environment A' calves to be invaded by micro-organisms from adult animals. The finding that the 'environment $A$ ' calves were free of ciliate protozoa suggested that this may have been the primary cause of their differences from the other groups of animals, a possibility which was consistent with the results shown in Fig. I. This view receives general support from the fact that the presence of protozoa has been shown to reduce the numbers of bacteria in the rumen (Eadie \& Hobson, 1962; Coleman, 1964, 1972), to affect the types present (Eadie \& Gill, 1971) and to influence their metabolic activity (Kurihara, Eadie, Hobson \& Mann, r968).

Experiments with pure strains of bacteria grown in continuous culture have shown that restriction of nutrients may lead to the bacteria having an increased total $\mathrm{N}$ content and decreased RNA-N:total N ratio (Herbert, r 96r). Although it must be borne in mind that the bacterial population in the rumen at any one time consists of a mixture of organisms at different stages of development, growing at different rates and made up of many different strains, this observation may be relevant to some of the variations which we have observed. It may help to explain the differences in nitrogenous bacterial constituents observed in calves reared in different environments if the establishment of protozoa in the rumen is considered to reduce the nutrients 
available for the bacteria. It may also help to explain the increase in RNA-N: total N ratio which was observed in the rumen bacteria of calves and cows some hours after feeding.

We wish to thank Dr D. F. Osbourn and Dr D. E. Beever for arranging the care of the calves kept at the Grassland Research Institute, Miss P. E. Lewis for general assistance, Dr H. Buttle and Mr S. Watson for fistulating the calves, Dr M. J. Latham for making protozoal counts and $\mathrm{Mr} \mathrm{D}$. R. Westgarth for the statistical treatments. Thanks are also due to Mrs S. J. Askew, Mr R. J. Merry and Miss P. N. Downes for helping with different aspects of the work.

\section{REFEREN CES}

Balch, C. C. \& Cowie, A. 'T. (1962). Cornell Vet. 52, 206.

Bergen, W. G., Purser, D. B. \& Cline, J. H. (I 968). F. Dairy Sci. 51, 1698.

Coleman, G. S. (1964). F. gen. Microbiol. 37, 209.

Coleman, G. S. (1972). F. gen. Microbiol. 71, I 17 .

Condon, R. J. \& Hatfield, E. E. (r970). F. Anim. Sci. 31, .037.

Eadie, J. M. \& Gill, V. S. (1971). Br.F. Nutr. 26, I 55 .

Eadie, J. M. \& Hobson, P. N. (1962). Nature, Land. 193, 563.

Gibbons, R. J., Doetsch, R. N. \& Shaw, J. C. (1955). F. Dairy Sui. 38, I147.

Heald, P. J. (I95 I). Br. F. Nutr. 5, 84 .

Henderickx, H. K., Demeyer, D. I. \& van Nevel, C. J. (1972). In Tracer studies on Non-protein Nitrogen for Ruminants p. 57. Vienna: International Atomic Energy Agency.

Herbert, D. (1961). Symp. Soc. gen. Microbiol. no. I I, p. 39 I.

Hoogenraad, N. J. \& Hird, F. J. R. (I970). Br. . Nutr. 24, I I 9.

Hungate, R. H. (1 966). The Rumen and its Microbes p. 126. London: Academic Press.

Jouany, J.-P. \& Thivend, P. (1972). Annls Biol. anim. Biochim. Biophys, 12, 679.

Katz, I. \& Keeney, M. (1964). Biachim. biophys. Acta 84, 128.

Kurihara, Y., Eadie, J. M., Hobson, P. N. \& Mann, S. O. (т968). F. gen. Microbiol. 5x, 267.

Lindsay, J. R. \& Hogan, J. P. (1972). Aust. F. agric. Res. 23, 32 I.

McAllan, A. B. \& Smith, R. H. (1969). Br. J. Nutr. 23, 671.

McAllan, A. B. \& Smith, R. H. (1972). Proc. Nutr. Sac. 3I, 24 A.

Mason, V. C. \& Palmer, R. (1971). F. agric. Sci., Camb. 76, 567.

Milwid, M. S., Oliver, J. \& Topps, J. H. (r968). S. Afr. F. agric. Sci. 1 1, 493.

Smith, R. H. ( 1969). F. Dairy Res. 36, 3 ×3.

Smith, R. H. \& McAllan, A. B. (1970). Br. F. Nutr. 24, 545.

Smith, R. H. \& McAllan, A. B. (1972). Proc. Nutr. Soc. 31, 28 A.

Smith, R. H. \& McAllan, A. B. (I973). Proc. Nutr. Soc. 32, 9 A.

Thompson, J. K. \& Hobson, P. N. (1971). J. agric. Sci., Camb. 76, 423.

Walker, D. J. (1965). In Physiology of Digestion in the Ruminant p. 206 [R. W. Dougherty, editor]. Washington DC: Butterworths.

Walker, D. J. \& Nader, C. J. (1970). Aust. F. agric. Res, 21, 747. 